\title{
STRATEGI ALTERNATIF MARKETING PERBANKAN DAN LEMBAGA KEUANGAN SYARIAH
}

\author{
Sofyan Rizal*
}

\begin{abstract}
Alternative Marketing Strategies of Banking and Islamic Financial Institutions. MUI's Fatwa about illegitimating of banking interest can be seen as an opportunity of Islamic banking and Islamic financial institutions to educate the public about the importance of operations in the Islamic financial institutions. This fatwa also marked that the emergency to receive interest in Islamic law has ended. Various alternative approaches in marketing can be done to work on segments of banking and Islamic financial institutions even in the middle of banking competitions. Alternative marketing approach that focuses on segment, marketing radical, and value creation, and spiritual advocate creation become very effective to face the competition of banking today. These are can be used in maintaining and even expanding the market share of Islamic banking.
\end{abstract}

Keywords: marketing, Islamic finance, Islamic banking

\begin{abstract}
Abstrak: Strategi Alternatif Marketing Perbankan dan Lembaga Keuangan Syariah. Fatwa MUI tentang keharaman bunga bank dapat dilihat sebagai suatu kesempatan dari perbankan syariah dan lembaga keuangan syariah untuk melakukan edukasi kepada masyarakat tentang pentingnya operasional pada lembaga keuangan syariah. Dengan keluarnya fatwa ini sekaligus menandai bahwa keadaan darurat untuk menerima bunga dalam syariat Islam sudah berakhir. Pelbagai pendekatan alternatif dalam marketing dapat dilakukan untuk menggarap segmen lembaga perbankan dan keuangan syariah, di tengah semakin kompetitifnya persaingan. Di tengah sumber daya yang terbatas dan kompetitor yang demikian kuat, maka pendekatan marketing alternatif seperti fokus pada segmen, radikal marketing dan penciptaan value, serta menciptakan spiritual advocate menjadi hal yang sangat efektif agar dapat terus mempertahankan pasar dan bahkan dapat melebarkan pangsa pasar perbankan syariah.
\end{abstract}

Kata Kunci: marketing, keuangan syariah, bank syariah

Naska diterima: 24 Mei 2011, direvisi 20 Oktober, dusetujui 27 Oktober 2011.

* Universitas Nasional Jakarta. Jalan Sawo Manila, Pejaten, Pasar Minggu, Jakarta. E-mail: sofyanrizal@yahoo.com 


\section{Pendahuluan}

Data Bank Indonesia, pada akhir 2008 dan awal 2009, mempublikasikan bahwa total aset perbankan syariah masih sebesar 2,19 persen dibandingkan dengan total aset perbankan nasional ${ }^{1}$. Hasil ini menunjukkan bahwa perkembangan perbankan syariah masih cukup lambat bila melihat rentang waktu sejak bank syariah (Bank Muamalat) berdiri.

Masalah perkembangan bank syariah yang lambat ini menjadi tema yang menarik untuk diteliti apa penyebabnya atau langkah apa yang dapat dilakukan agar perbankan syariah dapat lebih berkembang.

Bank syariah sesungguhnya memiliki modal utama yang besar untuk tumbuh dan berkembang, bahkan bersaing dengan perbankan konvensional. Modal itu antara lain, penduduk Indoensia yang mayoritas umat Muslim, yang secara langsung merupakan pasar yang potensial bagi produk-produk berbasis syariah, termasuk perbankan syariah. Fatwa MUI tentang haramnya bunga bank sudah dikeluarkan beberapa tahun yang lalu, juga dapat dilihat sebagai suatu kesempatan dari perbankan syariah dan lembaga keuangan syariah untuk melakukan edukasi kepada masyarakat tentang pentingnya operasional pada lembaga keuangan syariah. Fatwa ini memberikan kepastian hukum kepada nasabah dan calon nasabah bank syariah sekaligus memberikan payung hukum dari segi syariat bagi beroperasinya bank syariah dan lembaga keaungan syariah yang lain. Dengan keluarnya fatwa ini pula sekaligus menandakan bahwa keadaan darurat untuk menerima bunga dalam syariat Islam sudah berakhir.

Salah satu permasalahan yang coba diangkat dalam artikel ini adalah bagaimana cara yang tepat untuk meningkatkan pangsa pasar perbankan syariah dan lembaga keuangan syariah lainnya dengan strategi marketing yang tepat, lebih khusus lagi agar lebih terfokus, bagaimana sebuah bank syariah dapat memanfaatkan marketing yang tepat agar dapat meningkatkan pangsa pasarnya ditengah persaingan perbankan yang demikian ketat.

\section{Marketing Perbankan}

Marketing bagi suatu perusahaan merupakan hal yang sangat penting, termasuk bagi Industri perbankan. Marketing adalah suatu yang sangat luas dan berpengaruh terhadap perusahaan secara keseluruhan. Marketing tidak hanya sebatas menjual saja (selling), namun lebih luas dari itu adalah sebuah proses yang mencakup mulai dari perencanaan dan pelaksanaan penetapan harga, promosi, distribusi dari gagasan, produk ataupun jasa, untuk menciptakan

${ }^{1}$ Lihat dalam Statistik Perbankan Syariah dan statistik perbankan Indonesia, Bank Indonesia, 2008, di www.bi.go.id. 
pertukaran kepuasaan antara individu dan tujuan perusahaan². Pemasaran adalah suatu proses yang terencana yang dimulai dari merencanakan tujuan dari pemasaran itu sendiri, kemudian menggunakan konsep-konsep pemasaran, mengetahui lingkungan penasaran, menjalankan riset pemasaran, menentukan segmentasi dampai pada melakukan marketing mix.

Pemasaran perbankan adalah suatu proses perencanaan, pelaksanaan, dan pengendalian dari kegiatan menghimpun dana, menyalurkan dana, dan atau jasa-jasa keuangan lainnya untuk memenuhi kebutuhan dan kepuasan nasabahnya ${ }^{3}$. Masing-masing proses tersebut diperlukan dan saling mendukung sehingga pemasaran menjadi berhasil dan efektif dalam rangka mencapai tujuannya.

Pada pemasaran perbankan, misalnya, tujuan dari pemasaran harus di identifikasi, untuk apa dilakukan. Secara umum, tujuan dari marketing perbankan adalah memaksimumkan kepuasan nasabahnya melalui pelbagai macam pelayanan $^{4}$

Hal yang tidak kalah pentingnya adalah menganalisis lingkungan pemasaran. Lingkungan pemasaran biasanya dibagi menjadi dua, yaitu lingkungan mikro dan makro ${ }^{5}$. Lingkungan mikro, pada bank adalah manajemen bank itu sendiri, perantara pemasaran, Nasabah, pesaing, publik. Sedangkan lingkungan makro misalnya demografis, ekonomis, lingkungan alam, dan teknologi.

Segmentasi pasar juga merupakan hal yang sangat penting. Segmentasi pasar perlu dilakukan karena dalam suatu pasar terdapat banyak pembeli yang berbeda preferensinya. Segmentasi pasar ini, menjadi satu pijakan yang penting untuk memutuskan dengan strategi apa yang tepat pemasaran dilakukan.

\section{Preferensi Pasar Perbankan Syariah}

Penelitian BI tahun 2000 tentang preferensi masyarakat terhadap perbankan syariah di Jawa Barat, Jawa tengah, dan Jawa Timur dapat menjadi suatu data yang sangat berguna untuk menentukan segmentasi dan preferensi pasar

\footnotetext{
${ }^{2}$ Baca lebih lengkap dalam Kotler, Marketing Management, Millenium Edition, (New Jersey: Prentice-Hall, 2000), h. 4.

${ }^{3}$ Pemasaran perbankan, dapat digolongkan menjadi pemasaran jasa, di mana konsumen perbankan adalah nasabah perbankan. Lebih lanjut baca, Kasmir, Manajemen Perbankan, (Jakarta: RajaGrafindo Persada, 2007), h. 169.

${ }^{4}$ Kasmir, Manajemen Perbankan, h. 171.

${ }^{5}$ Kotler, Marketing Management, Millenium Edition, (New Jersey: Prentice-Hall, 2000), h. 12.
} 
dari perbankan syariah ${ }^{6}$. Beberapa hal yang penting dihasilkan dari survai tersebut antara lain bahwa pemahaman masyarakat mengenai keunikan dan keunggulan sistem produk/jasa perbankan syariah secara umum masih rendah. Dari segi motivasi masyarakat untuk menggunakan jasa perbankan syariah lebih dominan adalah faktor kualitas pelayanan dan lokasi, sedangkan faktor religius bukan menjadi satu-satunya faktor utama. Survai ini juga menemukan efektivitas tindakan edukasi perbankan syariah terhadap preferensi dan kecenderungan masyarakat untuk memilih bank syariah dan kecenderungan masyarakat yang juga lebih mempertimbangkan mutu pelayanan dan komitmen perbankan syariah terhadap nilai dibandingkan dengan faktor religius.

Berdasarkan hasil survai di atas, maka dapat digolongkan pasar potensial perbankan syariah menjadi dua, yaitu pasar spiritual dan pasar rasional. Pasar spiritual didefinisikan sebagai sharia loyalist, sedangkan pasar rasional dapat dibagi lagi menjadi floating market dan conventional market. ${ }^{7}$ Spiritual diwakili oleh golongan yang ingin berupaya dengan sepenuh hati untuk menjalankan prinsip syariah, sehingga prioritas yang paling penting dalam menggunakan bank adalah pertimbangan syariah. Pasar rasional adalah pasar dengan konsumen yang tidak hanya menjadikan sharia complient sebagai pertimbangan utama, namun juga faktor pelayanan, keuntungan yang didapat dan keunggulan-keunggulan dalam memilih bank syariah dibandingkan dengan bank konvensional.

Nasabah pada pasar emosional spiritual atau sharia loyalist adalah mayoritas umat Islam, yang berusaha berkomitmen dalam menjalankan agamanya dan cenderung fanatik, sehingga dapat dipastikan mereka akan memilih bank syariah, sebagai pertimbangan utama. Pasar ini bisa disebut captive market untuk pasar perbankan syariah. Namun, segmen spiritual ini, berdasarkan survai BI, tidaklah terlalu banyak. Hal ini juga dibuktikan dengan kasus keluarnya fatwa haramnya bunga oleh BI, yang tidak terlalu berdampak signifikan terhadap pangsa pasar perbankan syariah. Bahkan riset yang diadakan oleh Karim Busines Consulting, sebagaimana dikutip Hermawan, menegaskan bahwa pasar spiritual adalah pasar yang sangat kecil dan pasar rational emotional, merupakan pangsa

6 Baca lebih lengkap dalam Bank Indonesia, Ringkasan Pokok-pokok Hasil Penelitian Potensi, Preferensi dan Perilalu Masyarakat terhadap Bank Syariah di Pulau Jawa, Direktorat Penelitian dan Pengaturan Perbankan, Bank Indonesia, Desember 2000.

${ }^{7}$ Karim Business Consulting, dalam Hermawan Kertajaya, membagi pasar lembaga keuangan syariah menjadi tiga bagian, antara lain, sharia loyalist, floating market, dan conventional loyalist, sedangkan kertajaya mengelompokkannya menjadi spiritual market, emotional market, dan rational market. Sedangkan penulis cenderung mengelompokkan menjadi dua saja, yaitu spiritual market dan rational market. Baca lebih lengkap dalam Kertajaya, Marketing Syariah, (Bandung: Mizan, 2006), Cet. III, h. 167-168. 
pasar yang sangat besar bagi perbankan syariah ${ }^{8}$.

Pasar yang rasional adalah pasar yang lebih mengandalkan pertimbangan yang dianggap rasional, dan cenderung pragmatis. Mereka akan memilih bank syariah jika dianggap memberikan keuntungan, atau sedikitnya, mendatangkan keuntungan yang sama jika menjadi nasabah bank konvensional.

Pasar rasional, merupakan pasar yang luas dan masih terbuka lebar bagi perbankan syariah. Pasar inilah yang harus digarap oleh bank syariah dalam rangka melakukan ekspansi untuk terus berkembang. Pasar rasional akan mempertimbangkan hal-hal selain fanatisme, misalnya "asal tidak bunga atau riba", sehingga yang akan mereka pertimbangkan adalah faktor lain, seperti kualitas pelayanan.

Sebagaimana halnya produk jasa, perbankan memang dituntut untuk selalu menegdepankan kualitas jasa agar konsumen dapat terus loyal kepada bank tersebut. Kualitas jasa inilah yang menjadi ujung tombak dalam mengembangkan dan mempertahankan pasar perbankan syariah dan marketing adalah hal yang sangat penting perananannya dalam perusahaan jasa dalam rangka membangun dan menjaga loyalitas konsumen atau nasabah.

Dalam rangka mempertahankan pangsa pasar spiritual, membuka pasar rasional, memperbesar taget pasar, maka perbankan syariah memang harus bersaing dengan perbankan konvensional yang kebanyakan sudah besar dan lama. Inilah masalah yang besar yang dihadapi oleh perbankan syariah.

Perbankan konvensional memiliki banyak keunggulan kualitas pelayanan dibandingkan dengan perbankan syariah. Beberapa dimensi kualitas dari usaha jasa, seperti: access, availability, competence, performance, dan reability, menunjukkan bahwa perbankan konvensional lebih unggul dari perbankan syariah ${ }^{9}$. Sebagai contoh, dari segi access yang mudah, jika dibandingkan, maka perbankan konvensional jauh lebih unggul dari perbankan syariah. Banyaknya kantor cabang, kantor kas pembantu, dan jaringan yang masuk sampai ke pelosok daerah, memudahkan nasabah dalam mengakses bank. Perbankan

${ }^{8}$ Berdasarkan survai Karim Business Consulting, pangsa pasar yang terbesar bagi lembaga keuangan syariah justru ada pada floating market atau rational market, yang mencapai 720 Trilyun, dan yang paling kecil adalah pasar sharia loyalist, dengan hanya 10 triliun saja. Baca lebih lengkap dalam Kertajaya, Marketing Syariah, h. 167.

9 Beberapa ahli, antara lain Parasuraman, Garvin, Gronroos, Johnston, dan Zemke, menciptakan beberapa model kualitas jasa yang sangat mempengaruhi kepuasan konsumen terhadap jasa. Dari sekian banyak dimensi, sesungguhnya hampir memiliki kesamaan atau seringkali selalu muncul dalam setiap dimensi kualitas jasa, menurut penulis antara lain: reliability, permormance, features, availability, dan competence. Lebih lanjut baca dalam dalam Jasfar, Manajemen Jasa, Pendekatan Terpadu, (Jakarta: Ghalia Indonesia, 2005), h. 50-58. 
syariah, dengan jumlah kantor kas dan kantor cabang yang terbatas, tidak akan dapat bersaing dengan bank konvensional. ${ }^{10}$ Dari segi features produk, tentu produk perbankan syariah yang terbatas, bukanlah menjadi saingan bagi perbankan konvensional yang memiliki produk yang beragam dan menarik. Belum lagi jika melihat dari sisi promosi, perbankan konvensional menggunakan dananya begitu besar untuk promosi. Banyak bank yang berpromosi secara rutin di televisi, bahkan memiliki acara sendiri di stasiun TV swasta nasional dan secara rutin memberikan janji pelbagai macam hadiah yang akan diberikan oleh bank kepada nasabah ${ }^{11}$.

Menghadapi persaingan yang tidak seimbang tersebut, dari segi marketing, maka persaingan face to face atau persaingan langsung secara frontal pastilah tidak menguntungkan bank syariah karena keterbatasannya. Sebagai contoh, dalam hal promosi, bank syariah tidak akan mampu membayar iklan yang begitu mahal, jika harus tampil di pelbagai media massa. Pendekatan kepada nasabah, dengan pemberian hadiah yang fantastis, juga rasanya mustahil dilakukan oleh bank syariah. Belum lagi, kemudahan yang didapat oleh nasabah perbankan konvensional dalah hal akses kepada ATM dan kantor kas. Dalam hal margin bunga, yang dianggap sebagai persaingan harga dalam industri jasa lain, perbankan syariah akan sulit bersaing dengan bank konvensional, jika ingin memberikan bagi hasil yang lebih besar pada nasabahnya, dalam hal menggalang dana pihak ketiga (DPK), mengingat faktor "size" yang memungkinkan bank konvensional dapat lebih efisien dalam pengelolaan biaya operasional $^{12}$. Ketika komparasi ini kita bawa kepada bank syariah yang lebih kecil

${ }^{10}$ Sebagai gambaran umum, perbandingan jumlah bank dan jumlah kantor antara bank konvensional dengan bank syariah adalah sebagai berikut (data Januari 2009): Jumlah kantor bank konvensional di seluruh Indonesia sebesar 11.012 buah dari 123 bank. Sedangkan jumlah kantor 5 bank syariah ditambah 133 BPRS dan 25 UUS hanya memiliki 1.104 kantor pelayanan. Data lebih lengkap dapat dilihat dalam Statistik Perbankan, Bank Indonesia www.bi.go.id. Dengan jumlah kantor pelayanan yang sangat kecil dibandingkan dengan bank konvensional (hanya $10 \%$ saja), maka jelas dari segi akses kemudahan dalam jangkauan, bank sayariah jauh tertinggal dari bank konvensional.

${ }^{11}$ Gambaran lain dari begitu gencar dan besarnya dana promosi, kita bandingkan antara bank konvensional yang besar dengan bank syariah yang besar, yaitu BCA dan BMI. BCA menghabiskan dana untuk promosi sebesar 53.448 Juta rupiah selama Maret 2008-Maret 2009, sedangkan BMI menghabiskan dana untuk promosi 120.027 ribu, selama tahun 2008. Lebih jelas data-data tersebut, lihat dalam laporan keuangan BMI tahun 2008, dan Laporan keuangan BCA 2008-2009, di www.klikbca.com dan www.muamalatbank.com. Dengan dana puluhan milyar rupiah untuk promosi bagi sebuah bank konvensional, dibandingkan dengan hanya ratusan juta rupiah bagi bank syariah, tergambar, betapa dari segi promosi, keadaan memang tidak berimbang.

${ }^{12}$ Sebagai perbandingan, jika kita bandingkan margin bagi hasil deposito dan bunga deposito untuk tiga atau enam bulanan, maka data statistik menggambarkan perbankan konvensional dapat 
atau lembaga ekonomi mikro seperti BMT, maka hal ini jauh lebih sulit lagi. Perbankan konvensional kelihatan unggul dalam banyak hal ketika berbicara tentang penggarapan pasar rasional.

Mensiasati hal tesebut, maka perlu pendekatan yang berbeda agar perbankan syariah, apalagi yang sifatnya masih mikro seperti BMT, dapat eksis menghadapi persaingan dalam industri perbankan ini. Perbankan syariah perlu melakukan strategi marketing yang tepat dengan segala keterbatasan sumber daya mereka. Oleh karena itulah, pendekatan pemasaran radikal diperlukan oleh perbankan syariah.

\section{Langkah-langkah Strategi Marketing Alternatif}

Strategi marketing alternatif untuk menghadapi kedaan yang sangat kompetitif dengan segala keterbatasannya tersebut disusun dalam beberapa langkah. Langkah tersebut antara lain segmentasi yang fokus sebagai langkah awal dan kemudian melakukan strategi pemasaran dengan pendekatan beberapa taktik pemasaran alternatif untuk menggarap pasar segmented.

\section{Strategi Segmentasi Marketing}

Strategi awal untuk marketing perbankan syariah adalah identifikasi serta memanfaatkan segala peluang yang ada dipasar. Inilah yang dinamakan segmentasi. Di saat lain, segmentasi juga berusaha untuk melihat pasar berdasarkan pelbagai macam karakteristiknya yang ada.

Strategi segmentasi diperlukan bagi perbankan syariah, untuk mencari peluang segmen yang masih memungkinkan dengan strategi pemasaran yang tepat. Sebagaimana telah dibahas di atas, segmentasi umum dari pasar lembaga keuangan syariah adalah pasar spiritual dan pasar rational.

Semua segmentasi itu perlu untuk digarap, apalagi pangsa pasar ekonomi syariah yang jika hanya mendekati segmen spiritual saja dapat menyebabkan LKS kurang berkembang. Dengan pendekatan yang umum dan universal pasar rasional dapat digarap lebih lanjut.

Namun, sebagai langkah awal, dengan keterbatasan sumber daya yang ada, sebaiknya lembaga keuangan syariah melakukan langkah lebih lanjut setelah segmentasi, yaitu spesialisasi targeting. Targeting perlu dilakukan dengan

memberikan bunga yang relatif lebih besar dibandingkan dengan kemampuan perbankan syariah memberikan bagi hasil. Bunga rata-rata deposito per 12 bulan untuk bulan april 2009 sebesar 11,16\% dan untuk giro sebesar 2,80\%, dan tabungan sebesar 2,97 \%, sedangkan rata-rata perbankan syariah, untuk deposito 12 bulan, sebesar 9,10\%, giro sebesar 1,05\% sementara tabungan sebesar 3,35\% . Lihat lebih lengkap dalam data statistik perbankan syariah dan perbankan Indonesia, April 2009, Bank Indonesia, di www.bi.go.id. 
anggapan bahwa semakin kompetitif suatu lingkungan bisnis, maka semakin tinggi tingkat keberhasilan suatu strategi segmentasi yang terkonsentrasi ${ }^{13}$. Segmentasi untuk targeting dapat dilakukan dengan mempertimbangkan faktorfaktor lain selain perspektif agama, misalnya, basis geografi, demografis, dan psikografis.

Menurut Keagen, kriteria untuk menentukan targeting, sebagaiman dikutip Hermawan, dapat dilihat dengan pelbagai pertimbangan antara lain: ${ }^{14}$ market size dengan potential growthnya, potential competition, dan compatibility dengan feasibility. Pertimbangan itu antara lain apakah pasar yang dibidik potensial untuk berkembang? Apakah keunggulan kompetitif dan komparatif dari perusahaan dapat memenangkan persaingan atau berpeluan guntuk bersaning dengan pesaing, dan apakah perusahaan memiliki sumber daya yang seusai dan memadai.

Dengan segala keterbatasan yang ada, memang startegi segmentasi dengan berfokus pada segmen yang mungkin sambil terus memperbesar pasar diluar segmen, menjadi satu strategi yang jitu. Fokus pada segmen tertentu, membuat sumber daya yang dikerahkan akan lebih efektif, dengan strategi yang juga efektif dan efisien.

Sebagai contoh, sebuah BMT yang beroperasi dipasar, dengan berfokus pada nasabah pedagang pasar, maka la lebih mempunyai peluang untuk bersaing dengan bank lain. Ia lebih tahu medan pertemurannya, ia lebih megenal dan dekat secara personal dengan nasabah nya, la dapat bergerak dengan efisien dan menawarkan feature yang seusai dengan kebutuhan nasabah yang diketahuinya secara mendalam.

Sebuah bank syariah juga dapat berfokus pada beberapa segmen pasar di mana ia dapat lebih kuat bersaing dengan bank konvensional. Misalnya, sebuah daerah dengan tingkat religius yang tinggi, menjadi segmen yang begitu potensial. Segmen dengan penduduk Muslim yang berpendidikan juga menjadi suatu pasar rasional yang berpeluang untuk digarap dengan pendekatan edukasional tentang bank syariah.

Bank syariah juga dapat beraliansi strategis dengan BMT atau BPR atau pengurus masjid dan mushola, untuk pendekatan-pendekatan pemararan yang bersifat personal, local dan sesuai dengan kebutuhan, juga secara emosional dapat meningkatkan brand dari perbankan syariah terhadap market pasar sharia loyalist.

${ }^{13}$ Mussry, dkk, The Next Marketing Strategy, That's Work, (Jakarta: Gramedia, 2007), h. 23.

14 Keagen, dalam Global marketing Management, sebagaimana dikutip Kertajaya, dalam Marketing Syariah, (Bandung: Mizan, 2006), h. 170. 


\section{Taktik Alternative Marketing Perbankan Syariah}

Setelah melakukan segmentasi dan berfokus pada segmen, maka hal yang perlu ditindaklanjuti adalah bagaimana melakukan stategi dan taktik marketing dalam segmen tersebut. Begitu sengit persaingan dalam industri perbankan, menyebabkan hampir semua segmen dalam industri perbankan mengalami persaingan yang sama ketatnya. Kecilnya kue sharia loyalist yang diperebutkan oleh perbankan syariah dan lembaga keuangan mikro syariah, juga penetrasi perbankan konvensional yang saat ini sudah sampai masuk kepelbagai pelosok daerah, menjadikan semua segmen konsumen perbankan menjadi sangat kompetitif. Bagi perbankan syariah dan lembaga keuangan mikro yang memiliki sumber daya yang terbatas, maka strategi yang jitu dan efisien mutlak diperlukan. Perbankan syariah dan lembaga keuangan syariah membutuhkan taktik marketing alternative untuk mempertahankan segmen pasar dan menggarap segmen pasar lainnya.

\section{Radical Marketing}

Pelbagai konsep strategi alterntif dapat digunakan, antara lain strategi radical marketing ${ }^{15}$. Radical marketing, sebagai salah satu taktik alternative menggarap marketing, sangat tepat dengan karakteristik dan kondisi perbankan syariah dan lembaga keuangan syariah.

Memahami pemasaran radikal, tentu harus pula memahami pemasaran tradisional, sehingga kita mengetahui di mana letak perbedaannya. Pemasaran tradisional sebagaimana Hill dan Rifkin, ${ }^{16}$ selalu berkaitan dengan skala yang besar. Pemasar tradisional menganggap bahwa pemasaran adalah sesuatu yang sangat canggih dan ampuh, sehingga untuk melakukannya, diperlukan suatu usaha yang sangat besar, yang melibatkan sumber daya yang besar, dan anggaran periklanan yang begitu besar. Pemasar tradisional juga menganggap bahwa pemasaran adalah sesuatu yang sangat kompleks, dengan menggunakan teknik-teknik pemasaran akademis dasar, dengan strategi perang pangsa pasar, demografis, pengelolaan iklan media yang hebat, riset yang sangat mendalam dan luas, serta periklanan yang cerdas dan mahal. Pemasar tradisional juga cenderung mengarahkan sasarannya pada pusat pasar massal yang besar. Pemasar tradisional cenderung memfokuskan sasaran pemasarannya pada

${ }^{15}$ Radical marketing diperkenalkan oleh Hill dan Rifkin sebagai bentuk terobosan marketing bagi organisasi usaha yang memiliki sumber daya yang terbatas. Lihat lebih lanjut dalam Hill and Rifkin, Radical Marketing, (Jakarta: Gramedia 2003).

${ }^{16}$ dalam Hill and Rifkin, Radical Marketing, (Jakarta: Gramedia 2003), h. 13. 
segmen yang besar dan cenderung mengabaikan segmen celah dan sempit. Mereka cenderung melakukan "tembakan ke arah massal" dengan harapan pastilah akan mengenai sasaran. Pemasar tradisional, cenderung terpisah dari pelanggannya, seiring dengan bertambah besarnya organisasi. Hal ini terjadi kerana bertambah panjangnya birokrasi dalam organisasi yang besar. Pemasar tradisional cenderung terikat dengan patron dan formulasi pemasaran yang telah ada. Formulasi pemasaran seperti promotion, place, product, dan place, menjadi suatu hal yang mutlak dan tidak terbantahkan.

Karakteristik pemasar tradisional ini, seringkali memang mendatangkan keberhasilan, apalagi jika dilakukan dengan langkah yang cermat. Namun, langkah pemasaran tradisional ini tidak sepenuhnya dapat dilakukan oleh semua organisasi usaha. Perusahaan dengan sumber daya yang terbatas, sangat sulit untuk melakukannya, dan kadangkala hasil yang dicapai juga belum tentu optimal, karena tidak sesuai dengan keadaannya. Perusahaan dengan sumber daya yang jauh lebih kecil, membutuhkan alternatif lain yang mengakomodasi segala keterbatasan sumber daya tersebut. Oleh karena itulah mereka membutuhkan Pemasaran radikal . Pemasaran radikal memiliki ciri-ciri sebagai berikut :

Pemasar radikal cenderung terkendala oleh sumber daya yang sangat terbatas, dan terpaksa memanfaatkan anggaran-anggaran pemasaran yang jauh lebih kecil dari yang dipakai oleh pemasar tradisional. Kendala ini cenderung membuat pemasar radikal sangat fokus, dan selalu memncoba untuk menerapkan ide yang baru dan inovatif. Pemasar radikal juga cenderung mengarahkan fokus pada pertumbuhan dan ekspansi daripada upaya pengambilan keuntungan. Pemasar radikal lebih mementingkan untuk menciptakan value added pada konsumen, dibandingkan dengan mengambil profit sebanyak-banyaknya. Pemasar tradisional juga cenderung memiliki ikatan dan hubungan yang sangat intens dengan konsumen dan segmen pasarnya. Dengan hubungan inilah, pemasar radikal lebih memahami kebutuhan dan karakteristik pasar dan segmen yang dilayani ${ }^{17}$.

Pemasaran radikal mempunyai beberapa perangkat aturan yang dapat membuatnya efektif dan berjalan dengan baik. Beberapa perangkat aturan itu, sebagaimana dirumuskan oleh Hill dan Rifkin, ${ }^{18}$ antara lain: Pertama, adanya keterliatan yang intens pimpinan organisasi dalam seluk beluk pemasaran organisasinya. Pimpina organisasi, sampai setingkat CEO pun harus terlibat

${ }^{17}$ Baca lebih lengkap dalam Hill and Rifkin, Radical Marketing, (Jakarta: Gramedia 2003), h. 16-23.

${ }^{18}$ Hill and Rifkin, Radical Marketing, h. 28-45. 
secara mendetil dan mengendalikan fungsi pemasaran orannisasi. Kedua, membangun satu tim marketing yang sangat ramping dan efisien. Ketiga, membangun komunikasi yang dekat dengan konsumen. Bagi pemasaran radikal, kedekatan dengan konsumen adalah hal yang esensial pemasar radikal lebih suka terjun langsung menemui konsumen, mendengar keluhan mereka, membaca suratsurat kompalin mereka, dan membuat laporan riset-riset pemasaran hanya sebagai pelengkap. Tatap muka adalah suatu hal yang sangat efektif bagi pemasar radikal.

Keempat, menggunakan hasil riset dengan hati-hati. Pemasar radikal menggunakan hasil riset dengan prespektif yang sangat berbeda dari pemasar tradisional. Riset pasar digunakan sebagai pelengkap data konsumen, bukan sebagai pengganti suara konsumen. Kelima, pekerjakan hanya misionaris marketer. Misionaris marketer akan bekerja dengan sepenuh hati, dengan menghormati dan menempatkan pelanggan diposisi yang sangat tinggi. Keenam, menciptakan suatu komunitas pelanggan yang sangat loyal.

Inti dari semua poin di atas adalah dua tema besar dari pemasaran radikal, yaitu menciptakan pemasar dan organisasi pemasaran yang andal namun efisien dengan metode tertentu yang menempatkan konsumen sebagai subyek dan penentu serta membina hubungan yang istimewa dengan para pelanggan.

\section{Implementasi Pemasaran Radikal}

Apa yang paling mungkin diterapkan pada perbankan syariah dan lembaga keuangan syariah dalam segmen pasarnya adalah membangun kedekatan dan loyalitas konsumen. Sebuah perusahaan jasa, seperti perbankan, sangat mengandalkan kepuasan konsumen terhadap kualitas pelayanannya. Salah satu modal yang sangat baik untuk membangun kepuasan konsumen adalah dengan membangun kedekatan dengan konsumen. Jasfar berendapat, bahwa salah atu kunci kesuksesan suatu perusahaan jasa adalah dengan selalu bertindak bagaikan perusahaan kecil (acting small) ${ }^{19}$. Acting small adalah bertindak atau melayani konsumen dengan cepat, fleksibel, cepat, tanggap, dan dengan cara sangat pribadi.

Membangun kedekatan dengan konsumen dapat pula dilakukan dengan pendekatan spiritual marketing, karena spriritual marketing akan membantu perusahaan yang memiliki value yang unggul untuk dapat bersaing ${ }^{20}$. Spiritual

${ }^{19}$ Baca lebih lengkap dalam dalam Jasfar, Manajemen Jasa, pendekatan terpadu, (Bogor: Ghalia Indonesia, 2005), h. 222.

${ }^{20}$ Kertajaya, Markplus on Marketing, The Second Generation, (Jakarta :Gramedia, 2007), h. $22-23$ 
marketing akan membuat organisasi membangun kedekatan dengan konsumen dengan prinsip-prinsip spiritual marketing seperti jujur, berusaha membangun hubungan yang baik dengan konsumen, memiliki jiwa melayani yang tinggi, dan memastikan tidak ada kecurangan dalam setiap proses dan unit produksi.

Bagaimana cara membangun dan meningkatkan loyalitas konsumen, dilakukan dengan menambah value produk. Menambah value produk dilakukan dengan cara menciptakan brand yang kuat, memberikan service yang memuaskan dan proses yang efektif serta efisien. Organisasi harus menciptakan value sehingga pelanggan membutuhkan alasan yang lebih kuat untuk memakai jasa, yang lebih daripada sekadar feature produk, persaingan harga, atau akses produk yang mudah. Bersaing pada feature produk akan menyebabkan perbankan syariah sulit untuk bersaing di tengah kehebatan produk-produk yang ditawarkan perbankan konvensional. Bersaing dari segi harga, (dalam perbankan suku bunga atau tingkat bagi hasil), lebih sulit lagi. Perbankan konvensional, dengan modal yang kuat, size yang lebih besar, serta manajemen yang baik, tentu menjanjikan dan memberikan harga yang lebih kompetitif bila dibandingkan dengan perbankan syariah. Persaingan dari segi harga juga kurang sehat bagi perbankan syariah, di tengah modal yang terbatas. Akses yang mudah, adalah salah satu kelebihan perbankan konvensional. ATM dan kantor kas yang terdapat di mana-mana, bukanlah tandingan perbankan syariah.

Perbankan syariah harus punya value yang lebih dari sekadar hal tersebut. Untuk meningkatkan brand value, sebuah brand membutuhkan dukungan service yang prima. Service yang prima tidak akan terjadi tanpa adanya proses yang efektif dan efisien.

Sebuah contoh value yang sederhana, yang pernah dialami penulis, misalnya, di sebuah BMT yang tidak terlalu besar, ada layanan antar jemput pengambilan dan penyetoran uang dari rumah. Ini mungkin bisa disebut delivery order dalam usaha fast food. Ketika nasabah membutuhkan uang, tinggal menelepon bank yang bersangkutan untuk mengambil uang atau menabung sejumlah uang. Layanan ini mungkin sederhana dan tidak membutuhkan dana yang besar, namun dianggap jauh lebih bersifat eksklusif dan pribadi daripada layanan ATM yang mengharuskan nasabah mencari-cari atm terlebih dahulu. Dari segi keamanan, jelas jauh lebih aman daripada harus datang ke bank dan mengambil uang sendiri.

Service akan lebih terasa dan mempunyai value yang lebih baik, jika sebuah organisasi sudah dapat melampaui apa yang dinamakan customer satisfaction, untuk kemudian menjadi customer surprise. Costumer surprice terjadi jika seorang nasabah mendapatkan yang lebih dari yang mereka persepsikan. 
Pelbagai layanan yang sifatnya pribadi dan ekslusif, akan sangat berkesan bagi nasabah. Layanan seperti ini dimungkinkan, terutama bagi BMT yang masih memiliki jumlah nasabah yang terbatas. Layanan seperti di atas, yang dimungkinkan untuk organisasi yang kecil karena masih berfokus akan melahirkan costumer surprise ${ }^{21}$.

Customer surprise menawarkan value produk yang dihasilkan bukan hanya sebagai suatu produk, namun merupakan suatu solusi, bukan hanya memenui kebutuhan konsumen dengan produk yang sifatnya generik (umum) dan menjadi komoditas belaka, namun dapat melebihi harapan konsumen ${ }^{22}$.

\section{Menciptakan Spiritual Advocate}

Spiritual advocates adalah satu langkah lanjutan dari konsumen yang loyal. Jika pelbagai value yang diciptakan oleh bank syariah dapat menciptakan konsumen yang loyal, maka, agar lebih memiliki efek multiplier yang hebat, dalam rangka menciptakan pemasar radikal, adalah menjadikan konsumen sebagai tim pemasar organisasi. Bagaimana caranya? Melahirkan apa yang dinamakan "spiritual advocate" ${ }^{23}$. Spiritual advocate membuat efek dari marketing menjadi luar biasa, karena konsumen yang bersikap spiritual advocate akan menjadi marketer bagi oraganisasi.

Bagaimana menciptakan spiritual advocate tersebut, dapat dilakukan dengan cara, antara lain menciptakan komunitas-komunitas dan meningkatkan keterlibatan sosial di antara nasabah atau konsumen.

Penciptaan komunitas dimaksudkan untuk menciptakan rasa memiliki yang lebih besar dengan adanya jejaring sosial. Penciptaan komunitas adalah efektif memfasilitasi hubungan antar nasabah dan juga dengan perusahaan. Beberapa cara yang sederhana dapat ditempuh bahkan bisa disinergikan dengan educational marketing terhadap bank syariah, antara lain: facebook, bulletin, user group, bekerjasama dengan lembaga nirlaba, dan lain sebagainya. Penciptaan komunitas saat ini, dengan adanya teknologi informasi, bukan menjadi barang yang mahal. Sebagai contoh, bagaimana efektifnya facebook dalam menjalin jaring komunitas, dapat dimanfaatkan oleh perbankan syariah, untuk membuat komunitas antar nasabah. Membuat wibesite yang menarik, dan

${ }^{21}$ Lebih jelasnya konsep costumer surprise, lihat dalam Hermawan on Marketing, (Jakarta: Gramedia, 2006), h.224-226.

${ }^{22}$ Lebih jelasnya konsep solution dalam value ini, lihat dalam AB Susanto, dkk, Value marketing, Paradigma Baru Pemasaran, (Jakarta; Quantum Bisnis \& Manajemen, 2004)

${ }^{23}$ Spiritual Advocate adalah konsumen yang sudah pada taraf lebih tinggi dari konsumen loyal. Lebih lengkap tentang spiritual advocate ini, baca dalam Kertajaya, Markplus on Marketing, the Second Generation, h. 151-156. 
tampilan facebook yang unik, juga bukanlah sesutu yang mahal. Dengan pengelolaan jejaring sosial ini, nasabah bisa berkomunikasi, bertukar ide, berkeluh kesah secara langsung, mendapat informasi secara cepat, dan lain sebagainya. Bagi lembaga keuangan mikro yang kecil, bahkan dapat membuat semacam kelompok-kelompok nasabah, sebagai wadah komunikasi. Kelompok ini, meniru kesuksesan grament bank, dapat mennjadi tempat nasabah untuk belajar, berusaha, berkeluh kesah, tukar pengalaman dan lainsebagainya. Value yang ditawarkan oleh organisasi seperti ini adalah menciptakan solusi. Pendekatan yang digunakan adalah pendekatan konsultatif sehingga nasabah merasakan hubungan yang lebih erat lagi.

\section{Penutup}

Pelbagai pendekatan alternatif dalam markting dapat dilakukan untuk menggarap segmen lembaga perbankan dan keuangan syariah, di tengah semakin kompetitifnya persaingan dunia perbankan. Di tengah sumber daya yang terbatas dan kompetitor yang demikian kuat, maka pendekatan marketing alternative seperti fokus pada segmen radikal marketing dan penciptaan value, serta menciptakan spiritual advocate menjadi hal yang sangat efektif agar dapat terus mempertahankan pasar dan bahkan dapat melebarkan pangsa pasar perbankan syariah. []

\section{Pustaka Acuan}

Fisk, Peter, Marketing Genius, John Wiley \& Sons: USA, 2006.

Hill, Sam and Glenn Rifkin, Radical Marketing, Jakarta: Gramedia, 2003.

Jasfar Farida, Manajemen Jasa, pendekatan terpadu, Bogor: Ghalia Indonesia, 2005.

Kasmir, Manajemen Perbankan, Jakarta: RajaGrafindo Persada, 2007.

Kertajaya, Hermawan, Markplus on Marketing, The Second Generation, Jakarta: Gramedia, 2007.

Kertajaya, Hermawan, dan Sula, Muhammad Syakir Sula, Marketing Syariah, Bandung: Mizan, 2006.

Kertajaya, Hermawan, Hermawan on Marketing, Jakarta: Gramedia, 2006.

Kotler, Philips, Marketing Management, Millenium Edition, New Jersey: PrenticeHall, 2000.

Mussry, Jacky, dkk., The Next Marketing Strategy, That's Work, Jakarta: Gramedia, 2007.

Susanto, AB, dkk, Value Marketing, Paradigma Baru Pemasaran, Jakarta: Quantum Bisnis \& Manajemen, 2004. 